\title{
The Benefits and Constraints of Service Learning on Typography Class: Street Vendors' Banner Design Project
}

\author{
Elisabeth Christine Yuwono*, and Maria Nala Damajanti \\ Visual Communication Design Department, Faculty of Art and Design, Petra Christian University, \\ Siwalankerto 142-144, Surabaya, Indonesia
}

\begin{abstract}
Typography subject focuses on exploring typefaces using typical software and applying it to an artwork, such as a poster, advertisement, etc. In 2016, Typography 2 applied service-learning for the first time. Students were divided into several groups to make banners for street vendors in Surabaya city. This paper aims to determine the benefits obtained by participants of Typography 2 with the service-learning. In addition, to know the constraints faced as an evaluation of service-learning implementation. This study used qualitative methods, by collecting data from students' reflection on Typography 2 service learning project. The students' reflection consists of the learning they get and the obstacles or constraints. The results from service-learning implementation show many benefits are obtained, both in terms of academic and non-academic. It seems that non-academic benefits reveal more than academic benefits. Obstacles and constraints also faced during the implementation can be a meaningful input for service-learning implementation in the future. Implementation of service-learning in Typography class provides the different type and enriches case study in design subject. It also provides an assertion that service-learning as a method of learning is very good and can be applied in courses or other subject areas.
\end{abstract}

Keywords: Banner design, service-learning, street vendor, typography

\section{Introduction}

\subsection{Typography}

Visual communication design is a field of science that studies how to deliver messages (especially visually) effectively in order to be understood by the target audience. Emphasis on the visual side is important, as well as a differentiator for visual communication design compared to other scientific fields. Therefore, visuals become an important aspect of learning in visual communication design. Graduates of visual communication design are

\footnotetext{
* Corresponding author: xine y@petra.ac.id
} 
required to understand and master the visual language, also have a good visual sensitivity according to design rules.

Composition or layout is one application of visual sensitivity in visual communication design, also implementations of visual communication design that plays an important role in delivering messages visually. A composition or layout consists of various design elements, such as lines, shapes/fields, textures, images, colors, letters, etc. Each element has its own roles, which when combined will support each other for the message to be delivered. In this case, visual sensitivity is required in looking at the design elements as well as feeling the design principles that make up a composition.

As described above, the letter is one of the constituent elements of a design composition, which has its own complexity. In terms of anatomy, the letters have body parts that affect the quality of the letters to be recognized (legibility). Typeface (typeface) is also able to affect the level of reading (readability) words or sentences, which ultimately affect the process of delivering the message. Letters also have psychological abilities that potentially support the impression you want to appear on a message, or in other terms, the letters have characters. In short, many things need to be learned about the letters as part of the design elements. Science field that studies the letters, including how to arrange and use them in the designs is called typography. Typography is also one of the core courses in the Visual Communication Design, taught in the first semester (Typography 1) and second semester (Typography 2). Essentially, the course of Typography 1 examines the basics of letters, the anatomy of the letters, the character of the letters, and the principles of typography. While Typography 2 is more of a development or exploration of the letters, such as creating a new letter (new typeface) and the application of letters in a composition.

\subsection{Street vendors}

Street vendors or so-called PKL (Pedagang Kaki Lima) are small traders who sell on the roadside, generally mobile (move-not settled) due to limited capital. Gradually their way of selling is also evolving, as more and more customers approach, many of the vendors are permanent (semi-permanent) in a place or location using stalls or tables and chairs so that visitors can eat more comfortably. The characteristic of street vendors is the existence of banners are stretched to cover the front part of the stall. If the vendors have more money, both sides of the stall can be given additional banners. The other function of the banner as a shade from the heat and rain beside to inform the menus. As the years progressed, the originally humble fabric which was used to inform customers about the menus provided by the seller, the banner had become personality also serves as a sign or identity that distinguished one stall from the others.

Banners as one of the outdoor media generally consist of elements of letters and images. The process of arranging these elements into a single unity of harmony is called layout. In addition to become filler elements (letters and pictures), another element to consider is space or the size of the banner area. Rustan [1] revealed, primarily layout can be described as the arrangement of design elements in the surface area of the certain media to support the concept/message it carries. In this case, the banner is a medium to convey the concept or message about street vendors' marketing profile, for example the name of the shop and what is sold or offered at the stall. Wardani, Susandari, and Wahyurini [2] in their research noted that the visual identity of vernacular on street vendors street vendors had the potential to encourage the tourism industry in Surabaya, as an attraction for local and foreign tourists. They observed the visual identity of street vendors in Surabaya (Indonesia) and Singapore. Their results showed that globalization had a significant impact on the design of visual identity and banners on street vendors, which were seen in the increasing use of digital printing, photography, digital illustrations, and free images from the internet. It 
actually threatened the vernacular and local content that became the uniqueness or peculiarity of the visual identity of street vendors stalls. This Wardani, Susandari, \& Wahyurini's research showed the importance of visual identity on street vendors. This became one of the triggers of the topic design of street vendors banners as the study project in the Typography 2 .

\subsection{Service-learning}

As one method of learning, Hinck and Brandell in [3] defined the service-learning as a method that helped students to learn and grow through participation in services that meet the needs of society. According to Klink and Athaide in [3], especially in service-learning was the existence of educational experience where students moved to meet the needs of people and society while providing opportunities for students to learn and grow. In line with the above two opinions, Bringle and Hatcher [4] argued that service-learning was an educational experience where students participated in community ministry and reflect on their involvement in such a way as to gain further understanding of discourse and appreciation of social needs, discipline and civic responsibilities. Based on the three opinions above can be seen the emphasis on the activities undertaken by students in the fulfillment of the needs of the community. Efforts to meet or answer the needs of the community would require the right strategy. In this case, the student must have sufficient scientific knowledge and sensitivity in order to apply the science to problem-solving in real life. The reality faced will vary, depending on the situation and conditions at the time.

The final project on Typography 2 academic year 2015/2016 that implement a real project in the form of a redesign of a banner of PKL was the implementation of servicelearning. The students were assigned to look for the street vendors with a less attractive banner display in Surabaya. Furthermore, students should meet the owner of the stall and offer assistance to redesign the banner of the stall to be more interesting. If the stall owner agreed, the student started to create an alternative banner of the stall design. During the process of making alternate banner designs, there was the participation of supervisors and stall owners who had an impact on the design revision. Final approval of the final design to be realized was the street vendor decision. Upon final approval, students created an actual banner with selected designs. For that, students prepared the necessary equipment, such as fabric, paint, and brush. Only after equipment was available, students started sketching based on their designs, and paint with color paints. After completion, the student handed the banner to the street vendor and helped them to install it.

\subsection{Objectives}

This paper aims to determine the benefits obtained by students of Typography 2 from learning with the service-learning method. In addition, to know the constraints which were faced as an evaluation of the implementation of the lecturing by using service-learning.

\section{Method}

This study used qualitative methods, by collecting data from students' reflection on Typography 2 service learning project. The students' reflection consist of the learning they get and the obstacles or constraints. The writing of reflection is the final exam of the semester, so it is assumed that the students do the reflection well. For the purposes of this study, student reflection writing can be a fairly valid source of data. The reflection's guide consists of four questions. The first, what lessons are students received during Typography 
2 class that applied service-learning method. Lessons include academic insight; social interaction aspect during banner making process; and also personal feeling after completely finished banner project for the street vendor. Secondly, students were asked to write constraints they faced during interaction with stall owner and team, also how they solved it. Thirdly, what students thought about advantages and disadvantages of Typography service-learning project. The last, students were asked whether they interest or not to join another service-learning project.

\section{Findings}

\subsection{Benefits in academic}

From a number of reflections written by students, it can be seen the benefits they get, especially in terms of typography and visual communication design, through servicelearning activities designing street vendors' banner. Some of them are:

\subsubsection{Understand the design process and principles in typography}

Typography 2 is a subject for the second semester of the Visual Communication Design department. As a core subject, students get theories and principles in making the typeface and apply it in a layout design. Through service-learning, students can learn about the design process and principles in typography directly, because the project they created is a real project. Here is some students' statement when making reflections on lessons related to the design process and typography they acquired:

From this typography service-learning, I also learned how the techniques of making banner from sketch thumbnail to painting process. I also learned how to make the typeface digitally. (Ivanajayadi, 2016)

Applying the principles of typography I have learned so far such as kerning, spacing, and others on the banner that I make. And better understand the usefulness of typography. (Tanta, 2016)

In making this life I learned about a good technique of designing a banner. Lots of things to make a concern. Starting from kerning, proportion, layout, creativity, etc. The most important things about a street vendor's banner is the ease of reading the typeface used, so that people can immediately understand the message that will be delivered. (Waworuntu, 2016)

I can understand more the anatomy of letters and can make letters more consistent so that in applying them to the street vendor's banner design, it looks more tidy and consistent. In addition, I also studied the character letters in accordance with the character of street vendors to be applied so that it can show the banner more suitable. (Christanti, 2016)

\subsubsection{Learn to make the typeface fit the target market}

To understand the theory and principles of design as well as typography, students have been practicing only by creating fictitious designs, where their idealism can be poured as freely as possible to achieve the best results. But with the service-learning method where they 
have to create a real design for street vendors, they must pay attention to who the target market design will be. This is what they realize when doing a banner design project for street vendors stalls, as some of the following students expressed:

From the learning service-learning Typography I learned a lot how to make the typeface in accordance with the target market, how to make the typeface in accordance with the chosen stall (Ivanajayadi, 2016).

Through this service-learning I learned that not every typeface matches every place and condition. For example, a beautiful and elegant typeface for writing in cafes is actually not desirable and not suitable for use in coffee shops. Precisely the simple typeface preferred by street vendors (Febrina, 2016)

\subsubsection{Learn to create a design that is able to meet the client's wishes}

One of the important things in the world of work is how a designer is able to meet the client's desire in making the design. Often it goes against the designer's desires, so that the designer candidate needs to learn to suppress the personal desires and give priority to the client's wishes. The experience of this is certainly necessary so that the candidate designers can compromise with himself and be able to make the design acceptable to the client. Service-learning provides experience on this subject, like the expression of some of the following students:

Through this course I learned quite a lot, from how to interact and create a design that is in accordance with the wishes of the client. On the other hand, my perspective became wider. I am not only selfish to want to design as I want but I learned that my design is for clients so it must follow the client's taste so that it can satisfy the clients and try as much as possible the design can also be useful and effective. (Tammy, 2016)

Through this service-learning I am confronted directly with a client who has special requests, and I as a designer must be able to realize the demand of the client ... and not selfish or self-imposed. (Angelica, 2016)

Our group actually wants to design a banner with images to make it look better and interesting, but the owner of street vendors do not want any pictures, just writing. (Meliana, 2016)

\subsubsection{Gain enrichment of insight into other materials}

Generally, learning in typography only uses paper media and supporting tools such as a poster or watercolor paint. The task of making these street vendors' banner provide insight into other media, the fabric as one of the media that has different characteristics with paper, as well as supporting equipment such as wall paint which has very different characters with poster paint. It makes the students feel the experience of working with the media differently than usual. The experience of taste is quite important in sharpening sense as a designer.

In terms of science I got a science that I never get before that is painting on the fabric by using paint, drawing on the cloth. (Claudia, 2016) 
I understand a lot and know the kind of fabrics and tools needed in making this street vendor's banner. (Tanta, 2016)

I learned a lot about painting techniques on fabrics. In contrast to how to paint on the wall or paper, because the consistency of paint should be really considered. If too liquid then the paint will be widened on the fabric fibers and will give the impression not tidy. Meanwhile, if too thick, it will appear thick impression and accumulate. (Seputra, 2016)

\subsection{Benefits in non-academic things}

In addition to academic benefits, learning with service-learning method also provides nonacademic benefits. Often in general learning, non-academic things are relatively difficult or even neglected for the intended purpose. In fact, the ability of non-academic is not less important with academic ability. It is seen in the world of work, many entrepreneurs and educators complained about the lack of soft skills among college graduates [5]. Therefore, attention to the non-academic ability of students should also be improved. Based on the reflection of the students, it can be seen that service-learning is also able to contribute nonacademic benefits.

\subsubsection{Got new experience and better perception than ever}

The background of a person (student) also influences how the person is behaving and acting. Often the attitude and actions of a person, if not accompanied by a good understanding, can make a person narrow-minded and even cause problems in community life. Experience of the new things can bring positive benefits in opening insights and perceptions that are not necessarily true so far. Here's a student statement on the subject:

Honestly, I have never visited a street coffee vendor before. So it was quite weird when I first visited this street vendor. Initially, I thought it would be hard to interact with the owner of street vendors, but it was very easy from the beginning when we offered to make up the whole process until it was executed easily. (Tammy, 2016)

\subsubsection{Practice soft skills of students in communicating with clients}

Communication is a soft skill that is important and needed by everyone in all aspects. The importance of communication can be seen in our everyday life, for example, to convey feelings, express desires, and explain intentions and goals. The principle also applies to business or professional work. Good communication for professionals is necessary, one example is to impress the client. Mahajan [6] said, oral communication is commonly used in business and is one technique that can produce significant impacts. In order for effective communication, the company must know and understand the target audience or client. The markets are composed of consumers with different cultures, incomes, tastes, expectations, beliefs, norms and motives [7]. Service-learning gives students the experience to get to know clients with different backgrounds, and then communicate with them. It was as revealed by the following two students: 
In my opinion, being friendly and using polite language when interacting with street vendors is also important for the completion of this task. (Tammy, 2016)

I learned how to interact with older people and learn to understand their tastes. Incidentally the owner of the shop is an old woman named bu Darto. (Tanta, 2016)

\subsubsection{Practice students soft skills to express their opinions well}

The ability to express own opinion is an important skill needed, especially in professional career. Booher in [8] said the ability to express oneself orally and in writing is referenced as the single most important skill to career advancement. In a business setting, he warns that “... if you can't communicate your ideas with impact, your words do not inspire confidence in your recommendations". These are two statements of students about what they learned to express their opinions.

How should I be able to convince the stall owner to accept the work of our group, and I must learn how the owner wants the shop. I also train how to interact well with the outside community, how to express opinions and explain the design of our work to the owner of the stall until finally the stall owner agreed. (Ivanajayadi, 2016)

I also learned how to communicate well and intend to help people who can not afford to buy / replace their banner without offending or demeaning the person. (Tanta, 2016)

\subsubsection{Trigger empathy}

Empathy has various definitions. Zinn (1999) in [9] described empathy as the process of understanding a person's subjective experience by vicariously sharing that experience while maintaining an observant stance. Halpern (2003) in [9] described empathy is a skill learned or an attitude of life, which can be used to try to come into contact with someone, to communicate and understand others' experiences or feelings. Based on those definition, it is assumed empathy is soft skill to understand other's experiences or feelings. Morelli, Lieberman, and Zaki [10] said that imagining, recalling, observing, or learning of others' positive outcomes can trigger positive empathy. Fredrickson in [10] describe positive empathy positively correlates with improved personal and social well-being. Positive emotion has more benefits, such as promotes social bonding, making individuals more open to connecting and engaging with others. Further, Loewenstein in [10] said individuals high in positivity may relate to others' positive experiences more easily. Students who participated in this project convey their feeling about stall owner' reaction, that indicate their positive empathy:

I also feel very happy and touched by the reaction of Mrs. Darto as the owner of the street vendor who is happy with our giving. I feel happy to make other people smile through my work. (Tammy, 2016)

Our group and I personally initially just felt it was our duty and obligation because of the duty of the lecturer. But ... I feel valuable lessons especially satisfaction when the moment is over and when the owner of the stall owner is happy and smiling at our work. In fact, as I passed the street vendor with my family and saw our banner installed, I feel happy and glad to share with others even if it is just a banner but it turns out to mean for others. (Febrina, 2016) 
I can interact with the vendor owner and understand the value of his simplicity. (Ivanajayadi, 2016)

\subsubsection{Emerge positive self-confidence through capability}

Psychology Dictionary Online defines self-confidence as an individual's trust in his or her own abilities, capacities, and judgments, or belief that he or she can successfully face day to day challenges and demands [11]. Self-confidence also brings more happiness. Success is determined by confidence about abilities which made us happier. Also, our capabilities made us feel better, hence it will be more energized and motivated to take action and achieve goals. Some studies show benefits from self-confidence, for example children with high self-confidence perform better at school and, later in life, have higher job satisfaction middle age [11]. Based on pieces of information about self-confidence, it's good to build in students earlier. Through service-learning, it seems could help students raised selfconfidence, as shown in these statements below:

During the installation of street vendor's banner, I learned that in my knowledge of design study, we can give and serve the community through our work, and our work can be really useful, not just paintings that are hung in the name of beauty, but our work really used and very useful for those in need. And our work not only on the website or in the digital realm only, but also on the objects that almost every day we meet and we do not realize like the street vendors. (Tanta, 2016)

I feel happy when the owner of the street vendors receives our banner with pleasure, even keeping the goodies in good condition; I feel my own experience as a designer whose work is appreciated / well appreciated. (Nugroho, 2016)

\subsubsection{Practice team work}

Teamwork has focused on bringing out the best in a team to ensure self-development, positive communication, leadership skills and the ability to work closely together as a team to solve problems. Teamwork could evolve each member into cohesive units and share expectations for accomplishing group tasks, added to trust and support for one another and respect for individual differences. There is also increased productivity and creativity. It is also aimed at ensuring clear work objectives and a climate of cooperation and collaborative problem-solving. Further, teamwork enhances higher levels of trust and support [12]. Those positive values of teamwork implied on these students' written statements:

I also learned to work together in groups, because as designers we need to be able to work together on teams to make our projects work. (Christanti, 2016)

Through this service-learning we learn to work together in teams. If there is no compact cooperation and no self-awareness of each individual, then the process of painting the course will be long and tiring. (Seputra, 2016)

\subsection{Obstacles or Constraints Faced}

This project also faces obstacles in its implementation. Constraints that can be conveyed is the problem where the work of banners by students is very limited. The space available is very limited, and the room condition is also less than ideal for work with large media such as banners. 
In the process, this project takes a long time, approximately one month. In those days, there are some street vendors who have replaced their banner with new ones, or moved locations even changed business or even closed. This is because the characteristics of street vendors are dynamic, tend to change in a short time. But on the other hand, some students complained about the time of a month is relatively short.

Another obstacle that is quite often encountered is the response back from the owner of the street vendor that tends to accept student design when asked his opinion. For example, when the student asked, the owner only answered "yes", "just up to you ", or "I just accept it". Based on the findings of interviews with stall owners, most of them feel very grateful to have made banners, so it is inappropriate to give input design according to their wishes.

Some students feel the type of stall vendor that has been determined just made less flexibility in making choices. The majority want to be given the freedom to seek and determine their own street vendor so they can conduct surveys and get a street vendor that is more suited to their wishes, because some of them rarely come and do not really know the existence of street vendors.

\section{Conclusion}

From the implementation of a banner design project with service-learning on this typography class, many benefits are obtained. Not only in terms of academic, but also nonacademic benefits. When considered, the benefits of non-academic obtained quite a lot, even more than academic benefits. Soft skills or non-academic skills are important and necessary in the workplace, so it is good if each teacher also gives attention to it by including it in one of the learning objectives. The way that can be done is through the service-learning.

However, there were obstacles and constraints faced during the service-learning implementation. That remind us about the stalls owner' characteristics that are dynamic, tend to be simple and acceptable. That can be a meaningful input for the implementation of service-learning in the future.

Implementation of service-learning in one of the Visual Communication Design subjects, namely Typography, provides the different type and enriches case study in design subject. It also provides an assertion that service-learning as a method of learning is very good and can be applied in courses or other subject areas.

\section{References}

1. S. Rustan. Layout : dasar dan penerapannya [Layout : Its application and basic]. Jakarta : Gramedia (2014). pp. [in Bahasa Indonesia]. https://www.goodreads.com/book/show/6125774-layout

2. K.K. Wardani, H. Susandari, O.D. Wahyurini. Developing street food vendor's vernacular visual identity to support tourism industry in Surabaya. 2nd International Conference on Creative Industries, (Surabaya, Indonesia, 2013). http://personal.its.ac.id/files/pub/5237-oyn-dkv-oyn_tika_street\%20vendors_final.pdf

3. E. Akpabio. Sage Open Journal, July-September:1-7 (2012). http://journals.sagepub.com/doi/pdf/10.1177/2158244012460694

4. R.G. Bringle, J.A. Hatcher. Journal of Higher Education, 67, 2 (1996). https://www.vanderbilt.edu/oacs/wp-content/uploads/sites/140/Implementing-ServiceLearning-in-Higher-Education.pdf 
5. B. Schulz. NAWA Journal of Language and Communication, June:146-154(2008). https://pdfs.semanticscholar.org/c1d3/e21ea8496e2d828678cde2981aac1bd4ce3e.pdf.

6. R. Mahajan. IOSR-JHSS, 20, 12, II:36-39 (2015). http://www.iosrjournals.org/iosrjhss/papers/Vol20-issue12/Version-2/F0201223639.pdf

7. G.T. Yamamoto. Understanding customer value concept: key to success [Online] from http://www.opf.slu.cz/vvr/akce/turecko/pdf/Yamamoto.pdf (2007) [Accessed on 3 August 2017].

8. S.P. Morreale, J.C. Pearson. Communication Education, 57, 2:224-240 (2008). https://www.tandfonline.com/doi/abs/10.1080/03634520701861713

9. F. Ioannidou, V. Konstantikaki. International Journal of Caring Sciences, 1, 3:118123 (2008).

http://internationaljournalofcaringsciences.org/docs/Vol1_Issue3_03_Ioannidou.pdf

10. S.A. Morelli, M.D. Lieberman, J. Zaki. Social and Personality Psychology Compass, 9/2:57-68 (2015). http://www.scn.ucla.edu/pdf/Morelli(2015)SPPC.pdf

11. C. Ackerman, L. Ugelow. Self-confidence: 9 essential ways to become more selfconfident [Online] from https://positivepsychologyprogram.com/self-confidence/ (2016). [Accessed on 15 September 2018].

12. T.M. Fapohunda. IJER, 1, 4:1-12 (2013). http://www.ijern.com/images/April2013/23.pdf 